\title{
Culture shock
}

David DeVorkin

Inside NASA: High Technology and Organizational Change in the American Space Program. By Howard E. McCurdy. Johns Hopkins University Press: 1993. Pp. 215. $\$ 32.95, £ 27.50$.

WHEN government funding of institutions is cut back after a crisis or because of changing national policies or imperatives, what, if anything, do the institutions do to survive? Do they innovate and streamline through creative restructuring? Do they become rigidly complex bureaucracies intent on survival? Or do they simply fade away? And as these institutions fight for survival, how do they change? These are the questions raised by this impor-

tant book.

Howard McCurdy, professor of political science and public affairs at American University in Washington DC, has analysed the changes in NASA (National Aeronautics and Space Administration) during its first three decades. He finds that as NASA cut back on the size of its operations in the early 1970 s, the number of administrative staff at headquarters rose relative to the number of engineers and scientists; that a growing preference for contract management suppressed in-house research and development; and that a vigorous culture of testing and verification gave way to an ageing management preoccupied with survival and avoiding risks. These and other shifts, McCurdy contends, were most noticeable during the second and third decades of the agency, and meant that programmes and projects were chosen more to keep people in employment than to address

Flight for survival - launch of the Apollo 9 mission in 1969.

gramme, officials from the Air Force Ballistic Missile Program worked to strengthen project management within NASA. The resulting creative tension provided the necessary but temporary balance, McCurdy argues, between independent technical expertise and strong management. This "loose-tight" combination, according to McCurdy, is what made the Apollo project work, just as it did in other successful large-scale, hightechnology projects. But the unstable equilibrium did not last long; it started to shudder during the last phases of the Apollo project, and collapsed soon after.

McCurdy's analysis fits the available histories reasonably well. He roots out the causes of change, interpreting how NASA developed as an organization during its expansionist Apollo years and how it tried to satisfy its passion for manned $\sim$ space flight and the permanent human occupation of space at a time when the US government decided that it had better ways to spend its money.

It is an impressive and thoughtprovoking study, but there are problems with some of the details and methodology. First, interviews are delicate instruments. It is not surprising that firstgeneration NASA employees look back with pride on the early days of the agency, but with bewilderment on how their successors and - as some argue - their nation have squandered their legacy. McCurdy is at first overcareful not to dispute the testimonies of his interviewees. Only in the second half of the book does he introduce any counterevidence to allow readers to put the oral histories in context.

Interviews provide a useful reflection of self-image and attitude, but they are not, on their own, good sources of fact. In this re-

generation NASA professional employees (administrators, scientists and engineers). Using NASA's official histories and the standard (and still inadequate) literature on space history, he shows that the early NASA was a blend of many different cultures: Wernher von Braun's German-dominated group in the Army Ballistic Missile Agency at Huntsville; the laboratories of the National Advisory Committee for Aeronautics; rocketry groups from both the Naval Research Laboratory and the California Institute of Technology's Army contract operation at the Jet Propulsion Laboratory; and management specialists from the Air Force Ballistic Missile Program. The first three formed NASA in its first two years and fostered a strong emphasis on hands-on testing and verification. When the Apollo project was approved as a crash pro- spect, McCurdy might also have been more critical of earlier written sources that often similarly rely on oral testimonies. Finally, although outright blunders are rare, one stands out. He understates by a factor of 1,000 the cost of the Orbiting Astronomical Observatory and Ranger series. This weakens his point that the real cost of later missions such as the Hubble Space Telescope increased as their complexity grew. The actual increases are far less dramatic.

. But McCurdy is surely on the right track. His valuable book makes the literature on organizational cultures accessible and reveals new ways to look at hightechnology agencies.

David DeVorkin is at the National Air and Space Museum, Smithsonian Institution, Washington, DC 20560, USA. ational culture and institutional histories.

Such agencies could not enter the govern- 